\title{
MULTI-PROXY RECONSTRUCTION OF MIRE DEVELOPMENT IN THE PORĘBY WOJSLAWSKIE ECOSYSTEM (SANDOMIERZ BASIN, SOUTHEASTERN POLAND)
}

\author{
JACEK CHODOROWSKI, ANDRZEJ PLAK, IRENA AGNIESZKA PIDEK and RADOSŁAW DOBROWOLSKI \\ Faculty of Earth Sciences and Spatial Management, Maria Curie-Skłodowska University, \\ PL-20-718 Lublin, Kraśnicka av. 2 CD, Poland
}

Received 30 August 2012

Accepted 18 March 2013

\begin{abstract}
Multi-proxy analysis (sedimentological, palaeobotanical, geochemical data and results of radiocarbon dating) of the biogenic sediments from a small mire ecosystem in the Sandomierz Basin (SE Poland) is presented. The ecosystem contains a full hydroseral sequence from minerotrophic to ombrotrophic wetland. It is one of the few sites in this region which is so thoroughly investigated in terms of the palaeoenvironmental record. Changes in the water supply of the mire area, and consequently the changes in the plant and sediment succession, were well correlated with the regional tendencies in precipitation and temperature during the Late Glacial/Holocene transition and in the Holocene. Human impact is very well recorded in pollen diagram from the Subboreal period.
\end{abstract}

Keywords: multi-proxy analysis, peat, gyttja, radiocarbon dating, Sandomierz Basin, SE Poland.

\section{INTRODUCTION}

Mire ecosystems are great archives of palaeoenvironmental information, valuable as a source of information on climate change, hydrologic conditions and vegetation history (e.g. Dobrowolski et al., 2001; Bałaga, 2004, 2007a, 2007b; Chambers and Charman, 2004; Ross-Barraclough et al., 2004). The use of multiple proxies for reconstruction of changes in hydrological and climate conditions is a commonly practised method in lake and peatland environment research (Digerfeldt, 1988; Willis et al., 1995; Issmer, 2009; Dobrowolski et al., 2010; Lamentowicz et al., 2011). This method provides the basis not only for the detailed reconstruction of ecosystem's ecology, hydrology or sedimentology, but also for the evaluation of regional and over-regional changes in environmental conditions. It is also a basis for forecasting their changes in the future.
The aim of this paper is the reconstruction of changes in environmental conditions in the western part of the Sandomierz Basin (SE Poland). It was based on a detailed sedimentological, palaeobotanical and some geochemical analysis, supported by radiocarbon dating of the cores of biogenic sediments from a small isolated mire ecosystem representing the full developmental succession - from minerotrophic to ombrotrophic mire.

\section{STUDY SITE}

The research was conducted in the Poręby Wojsławskie mire ecosystem $\left(\gamma 50^{\circ} 16^{\prime} 33.56^{\prime \prime} \mathrm{N} ; \lambda 21^{\circ} 30^{\prime} 18.76^{\prime \prime} \mathrm{E}\right.$; area 7.9 ha, $185 \mathrm{~m}$ a.s.1.), which fills a depression area without outlet between dunes in the western part of the Sandomierz Basin macro-region (Kondracki, 2009, Fig. 1).

Corresponding author: J. Chodorowski

e-mail: jchodor@poczta.umcs.lublin.pl 
The dunes were formed in two phases: (1) from late Vistulian to the pre-Allerød period, and (2) from the Younger Dryas to the middle of the Preboreal period (Wojtanowicz, 1971).

The mire consists mainly of Sphagnum peat, Sphagnum-sedge and sedge peat. Tree stand is composed of Pinus sylvestris L. and Betula pubescens Ehrh. In the understorey the following species occur: Frangula alnus Mill., Padus serotina (Ehrh.) Borkh. And in the herb layer Rubus hirtus Waldst. \& Kit. Agg., Vaccinium myrtillus L., Vaccinium vitis-idaea L., Dryopteris carthusiana (Vill.) H.P. Fuchs, Oxalis acetosella L., Agrostis capillaris L., Luzula pilosa (L.) Willd., Molinia caerulea (L.) Moench. S., Festuca ovina L.S.Str.(determination of species by Magdalena Franczak - Department of Ecology Maria Curie-Skłodowska University in Lublin; botanical nomenclature follows Mirek et al., 2002). Moss layer is composed of Danthonia decumbens DC., Polytrichastrum formosum (Hedw.) G.L.Sm., Pleurozium schreberi (Willd. ex Brid.) Mitt., Brachythecium rutabulum (Hedw.) Scimp., Sphagnum capillifolium (Ehrh.) Hedw., Sphagnum palustre L. The soils are predominantly Histosols (FAO-ISRIC-ISSS, 1998).

At present the mire is of the ombrotrophic character with water supply primarily from precipitation. The character of water supply and drainage is, however, modified by human activity.

\section{MATERIAL AND METHODS}

In order to reconstruct the development of the Poręby Wojsławskie mire ecosystem (PW), sedimentological, palynological and geochemical approaches were applied.

\section{Sedimentological analysis}

Three pits and 23 cores were investigated (Fig. 1). Drill cores were extracted using a Russian peat-sampler with the box diameter of $5 \mathrm{~cm}$. Cores were taken along a geodetically determined transect at approximate intervals of $20-40 \mathrm{~m}$, (Fig. 2). Macroscopic lithofacial description of biogenic and mineral-biogenic sediments was made using the TroelsSmith system (Troels-Smith, 1955; Tobolski, 2000). Two sediment cores, termed PW-1 $\left(\gamma 50^{\circ} 16^{\prime} 33.20^{\prime \prime} \mathrm{N}\right.$; $\left.\lambda 21^{\circ} 30^{\prime} 22.07^{\prime \prime} \mathrm{E}\right) \quad$ and $\mathrm{PW}-8 \quad\left(\gamma 50^{\circ} 16^{\prime} 33.92^{\prime \prime} \mathrm{N}\right.$; $\left.\lambda 21^{\circ} 30^{\prime} 13.61^{\prime \prime} \mathrm{E}\right)$, were analysed in detail in the laboratory.

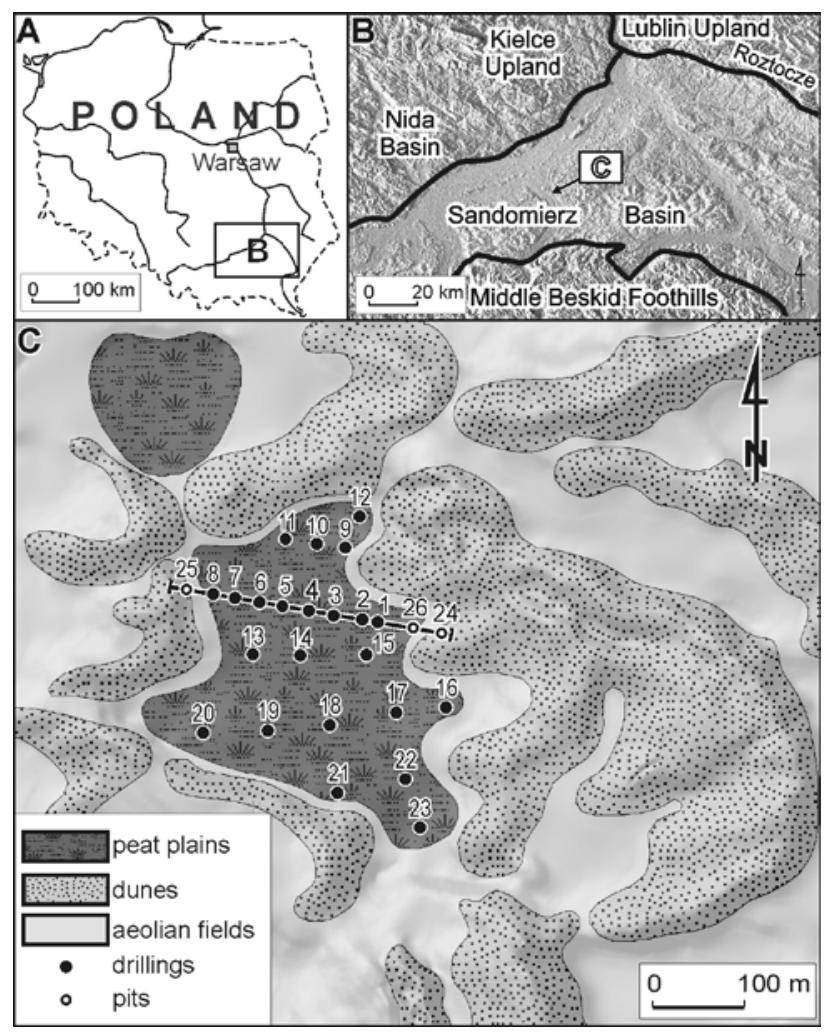

Fig. 1. Location of the Poręby Wojsławskie (PW) site: A - in Poland, $B$ - against the background of the Digital Terrain Model. Names of physico-geographical regions according to Kondracki (2009), C-geomorphological situation.

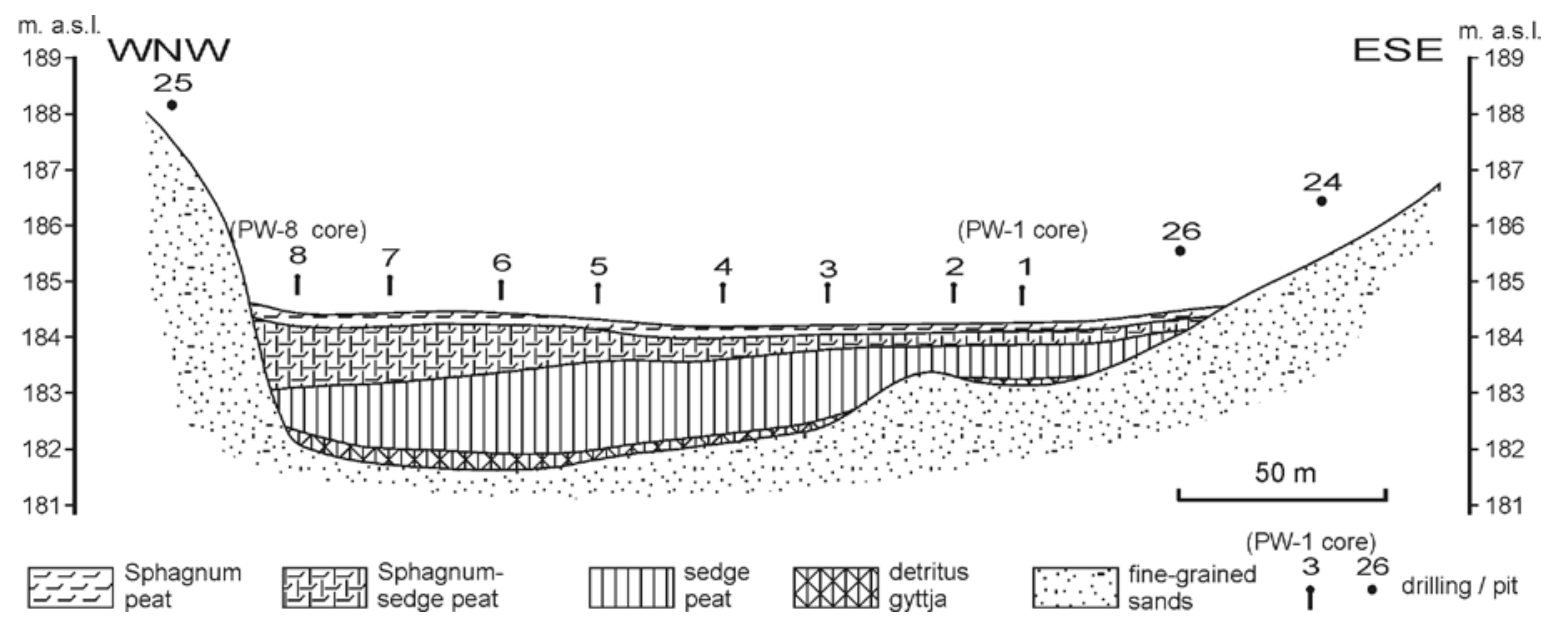

Fig. 2. Geological cross-section of Poręby Wojsławskie (PW) site. 


\section{Radiocarbon dating}

Radiocarbon dating was carried out in the Poznan Radiocarbon Laboratory using the accelerator mass spectrometer (AMS) method. Radiocarbon dating was performed for 4 samples from the PW-1 and PW-8 cores. In each case there were dated small macrofossils, $c a .1 \mathrm{~g}$ (Sphagnum spp. and Carex spp. in PW-1, and Carex spp. in PW-8), macroscopically selected from the deposits, representing separate lithological units (gyttjas, peat). Dates were calibrated using the OxCal v.4.1. software (Bronk Ramsey, 2009) with the IntCal09 calibration curve.

\section{Pollen analysis}

Samples $\left(1 \mathrm{~cm}^{3}\right)$ for palynological analysis were taken every $5-10 \mathrm{~cm}$ from the PW-8 core and macerated using the standard method of Erdtman's acetolysis (Erdtman 1969; Faegri and Iversen 1989). Carbonates were removed using $10 \% \mathrm{HCl}$, and the mineral fraction - using 40\% HF (Berglund and Ralska-Jasiewiczowa, 1986). Pollen spectra were counted on at least two microscopic slides $18 \times 18 \mathrm{~mm}$. Counting was continued until the pollen sum achieved 250-350 in the Late Glacial (Younger Dryas) deposits and ca. 700-800 in the Holocene deposits. The basic sum used for percentage calculations is the sum of tree and shrub pollen (arboreal pollen - AP), and of herb pollen (non-arboreal pollen - NAP), excluding the pollen of aquatic and reed-swamp plants, Pteridophyta and Bryophyta spores, as well as Pediastrum and Botryococcus algae colonies. In total 41 samples were analysed. The results are presented in the form of a pollen diagram (Fig. 3) prepared using POLPAL software (Nalepka and Walanus, 2003). Zonation of the pollen diagram follows the criteria published by West (1970) and Janczyk-Kopikowa (1987). Additionally numerical zonation by CONSLINK software available at POLPAL was applied.

\section{Geochemical analysis}

Geochemical analysis was carried out on the samples taken from the cores PW- 1 and PW- 8 every $5 \mathrm{~cm}$. There were measured: $\mathrm{pH}$ in water suspension - potentiometrically (Ostrowska et al., 1991); organic matter content based on loss on ignition at $550^{\circ} \mathrm{C}$ (Bednarek et al., 2004).

\section{RESULTS}

\section{Sedimentological analysis}

The biogenic deposits forming the mire reach a maximum thickness of $250 \mathrm{~cm}$ (in the western part of the ecosystem) and show stratigraphic zonation but little lateral variability (Fig. 2). The sequence consists of 4 main litostratigraphic units, chronologically coded 1-4 (Table 1). The lowest unit (unit 1) is a coarse-detritus gyttja (maximum thickness ca. $25 \mathrm{~cm}$ ), located directly on the fine-grained aeolian sands and documenting an early, short-lasting, shallow lake (paralimnic) phase of the ecosystem. This unit is covered by thick sedge peat, which constitute the main biogenic sedimentary unit

Table 1. Description of the deposits infillings Poręby Wojsławskie (PW) ecosystem.

\begin{tabular}{|c|c|c|c|}
\hline $\begin{array}{l}\text { Depth } \\
(\mathrm{cm})\end{array}$ & Lithology & Unit & $\begin{array}{c}\text { T-S Formula } \\
\text { (after Troels-Smith, 1955) }\end{array}$ \\
\hline \multicolumn{4}{|c|}{ PW-1 core $\left(\mathrm{y}^{2} 0^{\circ} 16^{\prime} 33.20^{\prime \prime} \mathrm{N} ; \lambda 21^{\circ} 30^{\prime} 22.07^{\prime \prime} \mathrm{E}\right)$} \\
\hline $0-10$ & Sphagnum peat, slightly decomposed, light-brown & 4 & $\mathrm{~Tb}^{0} 4$, sicc. 2, elast. 3, nig. 2, strf. 0 \\
\hline $10-20$ & Sphagnum-sedge peat, medium-decomposed, brown & & $\mathrm{Tb}^{2} 2, \mathrm{Th}^{2} 2$, sicc. 2, elast. 2, nig. 3, strf. 0, lim.1 \\
\hline $20-25$ & Sphagnum-sedge peat, slightly decomposed, light-brown & 3 & $\mathrm{~Tb}^{1} 3, \mathrm{Th}^{2} 1$, sicc. 2, elast. 2, nig. 2, strf. 0, lim. 0 \\
\hline $25-66$ & Sedge peat, strongly decomposed, brown & \multirow[b]{2}{*}{2} & $\mathrm{Th}^{3} 4$, sicc. 2, elast. 2, nig. 3 , strf. 0 , lim. 0 \\
\hline $66-71$ & $\begin{array}{l}\text { Sedge peat, strongly decomposed, with gyttja, single grains } \\
\text { of sand in floor, brown }\end{array}$ & & Th$^{3} 3$, Ld1, Gmin+, sicc. 2, elast. 1, nig. 3, strf. 0, lim. 0 \\
\hline $71-72$ & Coarse-detritus gyttja, grey-brown & 1 & Ld4, Th21, sicc. 2, elast. 1, nig. 2, strf. 0, lim. 1 \\
\hline $72-75$ & Fine-grained humus sand, with abundant gyttja, brown & \multirow[b]{2}{*}{ bedrock } & Gmin3, Ld1, sicc. 2, nig. 2, strf. 0, elast.0, lim. 1 \\
\hline $\begin{array}{l}\text { below } \\
75\end{array}$ & Fine-grained humus sand, brown & & Gmin4, sicc. 2, nig. 2, strf. 0, elast.0, lim. 0 \\
\hline \multicolumn{4}{|c|}{ PW-8 core $\left(\gamma^{5} 0^{\circ} 16^{\prime} 33.92^{\prime \prime} \mathrm{N} ; \lambda 21^{\circ} 30^{\prime} 13.61^{\prime \prime} \mathrm{E}\right)$} \\
\hline $0-25$ & Sphagnum peat, strongly decomposed, dark-brown & 4 & Tb04, sicc. 1, nig. 4, strf. 0, elast.0 \\
\hline $25-70$ & Sphagnum-sedge peat, strongly decomposed, dark-brown & \multirow{4}{*}{3} & $\mathrm{Th}^{4} 2, \mathrm{~Tb}^{3} 2$, sicc. 2 , nig. 3 , strf. 0 , elast. 2, Lim. 0 \\
\hline $70-80$ & Sphagnum-sedge peat, medium-decomposed, brown & & $\mathrm{Th}^{3} 2, \mathrm{~Tb}^{3} 2$, sicc. 2 , nig. 3 , strf. 0 , elast. 2 , lim. 0 \\
\hline $80-105$ & Sedge-Sphagnum peat, strongly decomposed, dark-brown & & $\mathrm{Th}^{4} 3, \mathrm{~Tb}^{31}$, sicc. 2, nig. 3, strf. 0, elast. 2, lim. 0 \\
\hline $105-160$ & $\begin{array}{l}\text { Sedge-Sphagnum peat, medium-decomposed, brown, } \\
\text { gyttja traces in places }\end{array}$ & & $\mathrm{Th}^{3} 3, \mathrm{~Tb}^{3} 1, \mathrm{Ld}+$, sicc. 2, nig. 3, strf. 0, elast. 2, lim. 0 \\
\hline $160-225$ & Sedge peat, medium-decomposed, with gyttja & 2 & $\mathrm{Th}^{3} 3$, Ld1, sicc. 2, nig. 3, strf. 0, elast. 3, lim. 0 \\
\hline $225-250$ & Coarse-detritus gyttja, brown & 1 & Ld2, Th${ }^{3} 2$, sicc. 2, nig. 3, strf. 0, elast. 3, lim. 1 \\
\hline $\begin{array}{c}\text { below } \\
250\end{array}$ & Fine-grained humus sand, grey-brown & bedrock & Gmin3, Ld1, sicc. 2, nig. 2, strf. 1, elast. 0, lim. 0 \\
\hline
\end{tabular}


(unit 2) with the thickness varying from $50 \mathrm{~cm}$ in the eastern part, to $120 \mathrm{~cm}$ in the western part of the ecosystem. The uppermost unit consists of Sphagnum-sedge peat (unit 3) replaced by Sphagnum peat in the upper layers (unit 4). Total thickness of peat reaches $160 \mathrm{~cm}$. These peat document the progressive change in the character of the mire supply - from groundwater (= minerotrophic mire) to precipitation supply (= ombrotrophic mire).

\section{Radiocarbon dating}

The results of radiocarbon dating are expressed as radiocarbon ages BP with associated uncertainty and presented on Table 2.

\section{Pollen analysis}

The local pollen assemblage zones (L PAZs) distinguished in the pollen diagram (Fig. 3) were related to chronostratigraphic units according to Mangerud et al. (1974). Due to the scarcity of radiocarbon dates the pollen zonation was additionally supported by the well-dated pollen diagrams from the neighbouring sites, published among others by Nalepka et al. (2005) and Kołaczek (2007). Pollen spectra of the samples taken from a depth of 245-250 cm (base of the biogenic sediments, Fig. 3 LPAZ 1) showed a high content of NAP (frequent Artemisia, Chenopodiaceae) and relatively frequent Juniperus, as well as the presence of Ephedra distachya t. and Betula nana. These samples most probably represented the Late Glacial period of Younger Dryas (Mangerud et al., 1974). The vegetation cover, which was reconstructed on the basis of pollen data, is consistent with the one described by Latałowa (2004). The high content of Botryococcus shows that the site could have been a shallow lake with lakeside reed belt (presence of the Phragmites pollen). The sedge-moss mire was forming around this lake, which was indicated by a significant content of Cyperaceae pollen and Musci spores.

The LPAZ 2 was related to the Preboreal period (Fig. $3)$. The pollen spectra $(240$ and $210 \mathrm{~cm})$ were dominated by Pinus and Betula, with a constant occurrence of elm (starting at $240 \mathrm{~cm}$ ). Simultaneously, the percentage values of typical Late-Glacial elements (Betula nana t., Chenopodiaceae, Artemisa, Juniperus, among others) decreased. Elm pollen curve and sporadically occurring grains of taxa such as Alnus, Quercus, Corylus, Fraxinus, and the beginning of constant occurrence of Humulus, as well as the continuous occurrence of Filipendula and Thalictrum (also the numerous spores of Filicales monolete). The obtained picture of vegetation development is consistent with these described by Latałowa (2003), Ralska-Jasiewiczowa (2004) and Zachowicz (2004). The above conclusions were confirmed by radiocarbon dating from 242-245 cm (9360-9200 cal BC). The lake became shallower (as indicated by a gradual disappearance of Botryococcus) and the surrounding reed belt gradually disappeared through the Preboreal. The mire contained Sphagnum but could have been transitional mire with the presence of Menyanthes trifoliata and Equisetum. The pollen spectra of the LPAZ 3 were dominated by Corylus, with significant content of pollen of thermophilous trees (Ulmus, Tilia, Quercus) and Alnus, probably representing the Boreal period characterized by the dominance of hazel (Latałowa, 2003; Ralska-Jasiewiczowa, 2004). This zone also showed a decrease in the percentage values of the pollen of tree birches, as well as the first maximum of Alnus (Fig. 3 - LPAZ 3). The occurrence of single pollen grains of Fagus, Abies and Carpinus in the sample from a depth of $205 \mathrm{~cm}$, correlated with a decrease in the organic matter content in the sample, suggested an accidental admixture of younger deposits. Worth attention were the sporadic presence of the Ceratophyllum hairs and the presence of Myriophyllum spicatum and Nymphaea alba pollen, which probably indicated a slightly higher water level. During the Atlantic period, represented by the pollen spectra of the LPAZ 4 and lower part of the LPAZ 5, the pollen values of Alnus, Quercus, Fraxinus, Tilia increased, Acer pollen appeared, Carpinus and Fagus pollen occurred sporadically, while the percentages of pine decreased significantly in the pollen spectra. This section

Table 2. Results of radiocarbon dating of organogenic deposits from the $P W-1$ and $P W-8$ cores.

\begin{tabular}{|c|c|c|c|c|c|}
\hline \multirow{2}{*}{ No. } & \multirow{2}{*}{$\begin{array}{c}\text { Sample name } \\
\text { /depth/ }\end{array}$} & \multirow{2}{*}{ Lab. No. } & \multirow{2}{*}{$\begin{array}{l}\text { Age 14C } \\
\text { (BP) }\end{array}$} & \multicolumn{2}{|c|}{ Calibrated age (cal BC) } \\
\hline & & & & range $68.2 \%$ & range $95.4 \%$ \\
\hline \multicolumn{6}{|c|}{ PW-1 core ( $\left(50^{\circ} 16^{\prime} 33.20^{\prime \prime} \mathrm{N} ; \lambda^{2} 1^{\circ} 30^{\prime} 22.07^{\prime \prime} \mathrm{E}\right)$} \\
\hline 1 & $\begin{array}{c}\mathrm{PW}-1 \\
/ 20-25 \mathrm{~cm} /\end{array}$ & Poz-11043 & $5200 \pm 40$ & $\begin{array}{l}4040-4010(30.8 \%) \\
4000-3970(37.4 \%)\end{array}$ & $\begin{array}{c}4230-4200(2.2 \%) \\
4160-4130(4.2 \%) \\
4070-3950(89.0 \%)\end{array}$ \\
\hline 2 & $\begin{array}{c}\mathrm{PW}-1 \\
/ 66-71 \mathrm{~cm} /\end{array}$ & Poz-10875 & $4780 \pm 40$ & $\begin{array}{c}3640-3630(8.4 \%) \\
3600-3530(59.8 \%) \\
\end{array}$ & $\begin{array}{l}3650-3510(88.2 \%) \\
3420-3380(7.2 \%) \\
\end{array}$ \\
\hline \multicolumn{6}{|c|}{ PW-8 core (y50¹6'33.92"'N; $\left.\lambda 21^{\circ} 30^{\prime} 13.61^{\prime \prime} \mathrm{E}\right)$} \\
\hline 3 & $\begin{array}{c}\text { PW-8 } \\
/ 105-110 \mathrm{~cm} /\end{array}$ & Poz-10728 & $5490 \pm 40$ & $\begin{array}{l}4370-4320(53.1 \%) \\
4290-4270(15.1 \%)\end{array}$ & $\begin{array}{c}4450-4420(9.9 \%) \\
4400-4310(64.9 \%) \\
4300-4260(20.7 \%)\end{array}$ \\
\hline 4 & $\begin{array}{c}\mathrm{PW}-8 \\
/ 242-245 \mathrm{~cm} /\end{array}$ & Poz-10729 & $9800 \pm 50$ & $9300-9250(68.2 \%)$ & $9360-9200(95.4 \%)$ \\
\hline
\end{tabular}




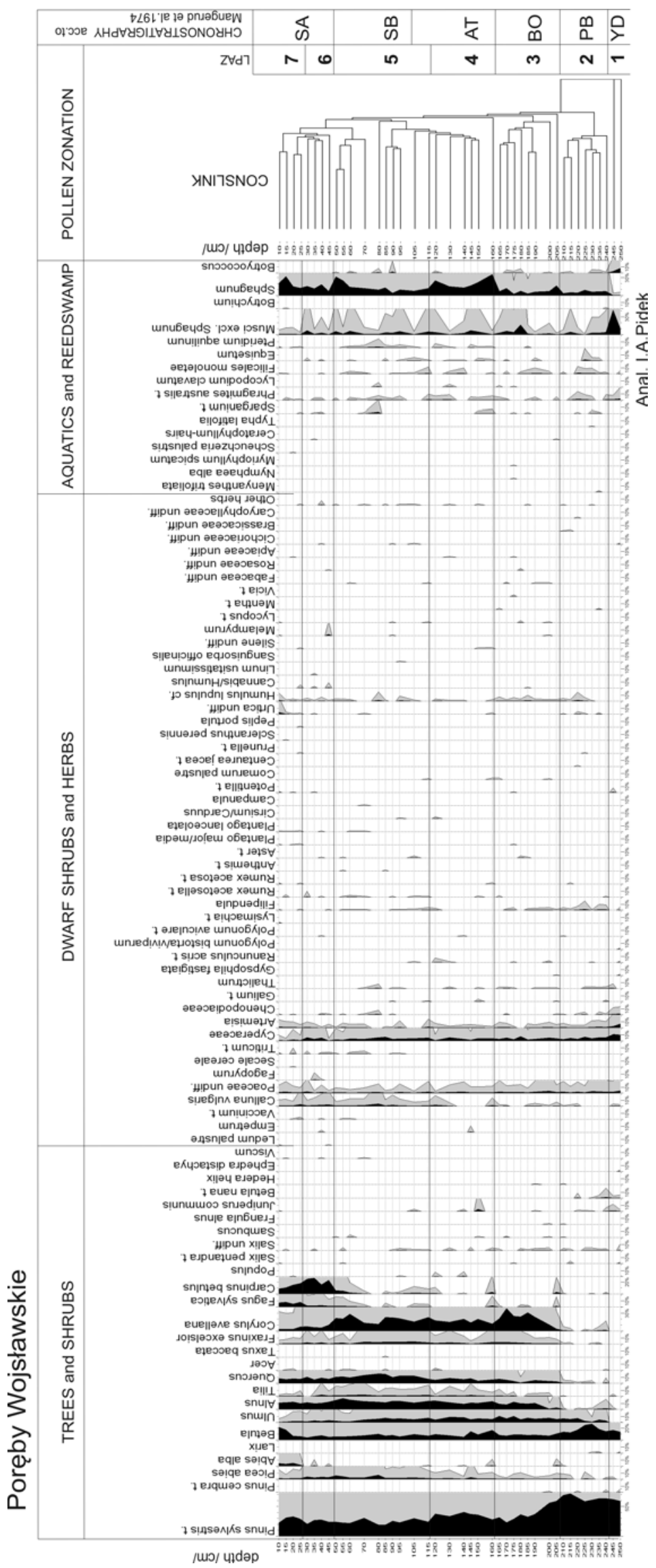


of the diagram represented the climatic optimum of the Holocene and is consistent with the description by Tobolski (2004). Important was the occurrence of the first anthropogenic indicators (frequent Pteridium aquilinum spores). Based on the fluctuations of the Phragmites and Sparganium t. pollen values, one may suspect that the water fluctuations with a phase of water level increase occurred. It is possible that the increased precipitation caused a renewed formation of the lake and the formation of the reed belt. The decrease in the elm pollen percentages in the sample from the depth of $115 \mathrm{~cm}$ indicated the possible transition between the Atlantic and Subboreal periods (Fig. 3 - LPAZ 5). Similar elm decline and the subsequent start of Carpinus, Fagus pollen curves and increase in Alnus and Calluna vulgaris pollen percentages were registered also in the Stanisławice profile (Nalepka et al., 2005) and the Krasne one (Kołaczek, 2007). The radiocarbon date from the depth of $105 \mathrm{~cm}$ (4400$4310 \mathrm{cal}$ BC) correlated well with the palynological data. The upper part of the LPAZ 5 and lower part of the LPAZ 6 represented possibly the Subboreal. During this period, fluctuations of the curves of thermophilous trees and hazel were observed in the pollen diagram. This could be caused by human activity and/or by climate changes (see discussion in Latałowa, 2003). In particular, the diagram showed the increase in Quercus pollen values - characteristic of the Subboreal period - accompanied by high pollen values of Corylus. The anthropogenic phase was particularly visible in the $70-80 \mathrm{~cm}$ samples (Triticum t. and Plantago lanceolata pollen, among others). The increase in Botryococcus algae in the second half of the Subboreal period, as well as the renewed slight expansion of the reedswamp vegetation, represented by Sparganium and Phragmites, probably indicated elevated water level due to an increased wetness of climate. The Subatlantic period began (upper part of the LPAZ 6 and LPAZ 7) with a significant decrease in the pollen curves of Ulmus, Quercus, Alnus, Fraxinus, while constant curves of Carpinus and Fagus appeared and were characterized by gradually increasing values. This pattern of tree succession is typical for the Subatlantic and is consistent with vegetation changes described among others by Latałowa (2003) and Makohonienko (2004). Significant was the occurrence of Picea pollen and also the appearance of Abies pollen in the upper section of the diagram. Initially, the water level was higher (Chironomidae mandibulae in the sample from a depth of $55 \mathrm{~cm}$ indicated of the presence of open water). Then, the area of the reed belt with Sparganium and the mire probably increased again (higher values of Sphagnum spores, the presence of Botrychium).

The last analysed sample was taken from a depth of $10 \mathrm{~cm}$. Most probably, the diagram did not include the youngest section of the Subatlantic period (strongly decomposed peat and thus oxidative conditions resulting in the destruction of pollen and spores).

\section{Geochemical analysis}

Organic matter. The Poręby Wojsławskie mire (PW) is characterized by a considerable content of organic matter in the whole examined period (Fig. 4). Peat layers rich in organic matter could have been related to the phases of decreased activity of relief-forming processes connected with periodic climate amelioration or weak anthropopressure. A decrease in peat growth, and the resulting increase in the mineral material (ash) probably indicated stronger erosion due to climate changes or anthropogenic deforestation (Ralska-Jasiewiczowa and Starkel, 1988; Macaire et al., 2006; Domińczak and Okupny, 2010).

pH. The $\mathrm{pH}$ of the analysed peat is acidic in both cores. (Fig. 4). The lowest $\mathrm{pH}$ values were characteristic of the top layers of Sphagnum and Sphagnum-sedge peat. This tendency probably indicated a greater significance of precipitation in the formation of analysed mire and encroachment of plant species preferring strongly acid habi-
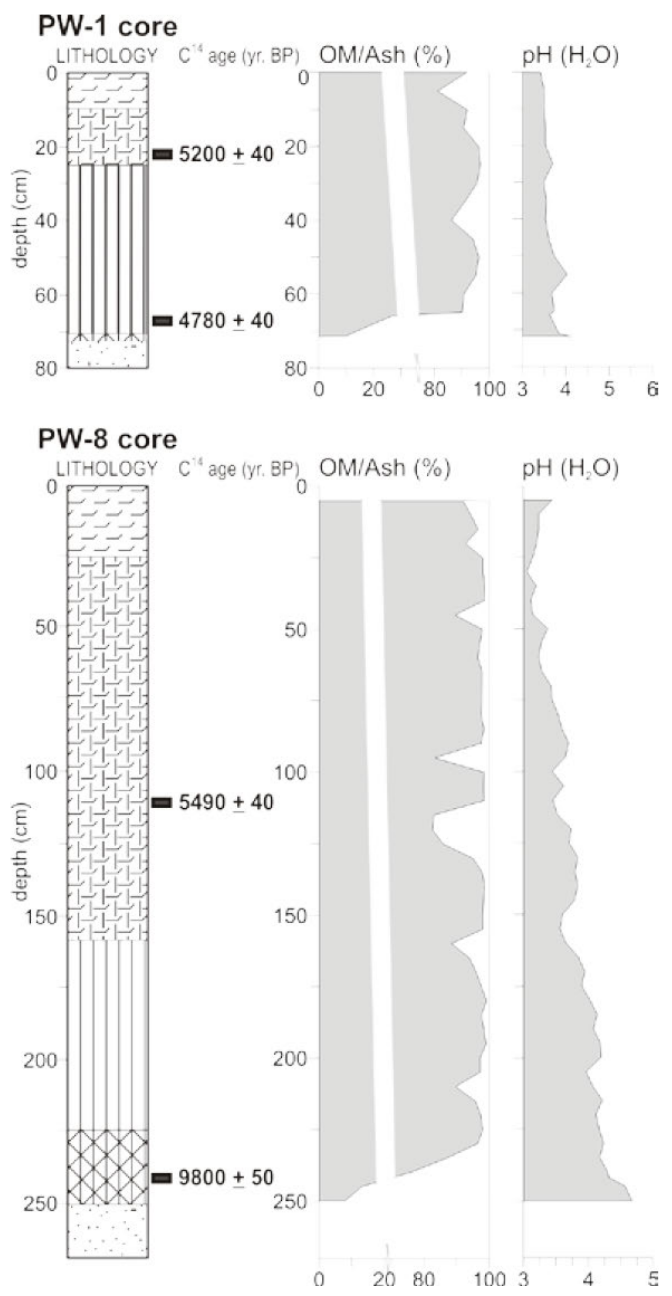

Fig. 4. Lithology, organic matter/ash (OM/Ash) contents and $\mathrm{pH}$ of infilling deposits of the Poręby Wojsławskie (PW) site. Symbols explanations as in Fig. 2. Calibration ages as in Table 2. 
tats (e.g. peat moss of Sphagnum genus). Strong acidification of the top layers in the examined mire could have been also influenced by land use (mostly coniferous forests with Pinus sylvestris monoculture).

\section{THE MODEL OF MIRE ECOSYSTEM EVOLU- TION IN THE LIGHT OF CLIMATE CHANGES IN THE LATE GLACIAL/HOLOCENE TRANSITION AND IN THE HOLOCENE}

Younger Dryas. The data indicates the aeolian (deflation) genesis of the depression in which the mire formed (Fig. 5). The formation of the basin could be unequivocally connected to the aeolian processes occurring in the Younger Dryas, which are commonly assumed to be the main phase of the dune formation processes in this region (Wojtanowicz, 1971; Nowaczyk, 1986). At the close of the Younger Dryas a gradual rise of groundwater level occurred, which resulted in waterlogging of the deepest parts of the basin, and in the start of biogenic deposition. Initially, it was a shallow water-body with a coarse-detritus gyttja in the bottom. It resulted from progressive changes of climate (increase in mean annual air temperatures) and hydrological conditions (permafrost degradation).

Preboreal period. The turn of the Late Glacial and the Holocene and the beginning of the Preboreal was characterized by expansion of boreal pine-birch forest and beginning of elm riverine communities (Latałowa, 2003; Ralska-Jasiewiczowa, 2004). A gradual increase of the lake area and depth of water was noticeable. The basin-like, paralimnic character of the biogenic sedimentation was documented by a high content of Botryococcus. The lake was gradually covered by the reed belt (presence of Phragmites pollen) and a sedge-moss mire developed in the surrounding area (high percentages of Cyperaceae pollen and Musci spores). At the end of the Preboreal period, the sedimentation conditions changed from paralimnic to paludic. It was registered usually in the lithologic record (beginning of sedge peat accumulation) and in the pollen spectra (disappearance of Equisetum pollen and decrease in the percentages of Spargani$u m$ and Typha). The forming mire was most probably of the transitional mire character, which was indicated by a significant content of Sphagnum and the presence of Menyanthes trifoliata. According to Ralska-Jasiewiczowa and Starkel (1988), a lowering of water level and a warming of climate was the cause of the overgrowth of small lakes in the period between 9900 to $9200 \mathrm{BP}$.

Boreal period. In the Boreal period, further development of peat occurred in the lake, which was indicated by a higher content of organic matter. Clear fluctuations of groundwater level were documented in the sedimentological and palynological data (compare RalskaJasiewiczowa, 2004). High resolution record from several German lakes also showed the phase of high water levels during the Boreal period. This was followed by a signifi-
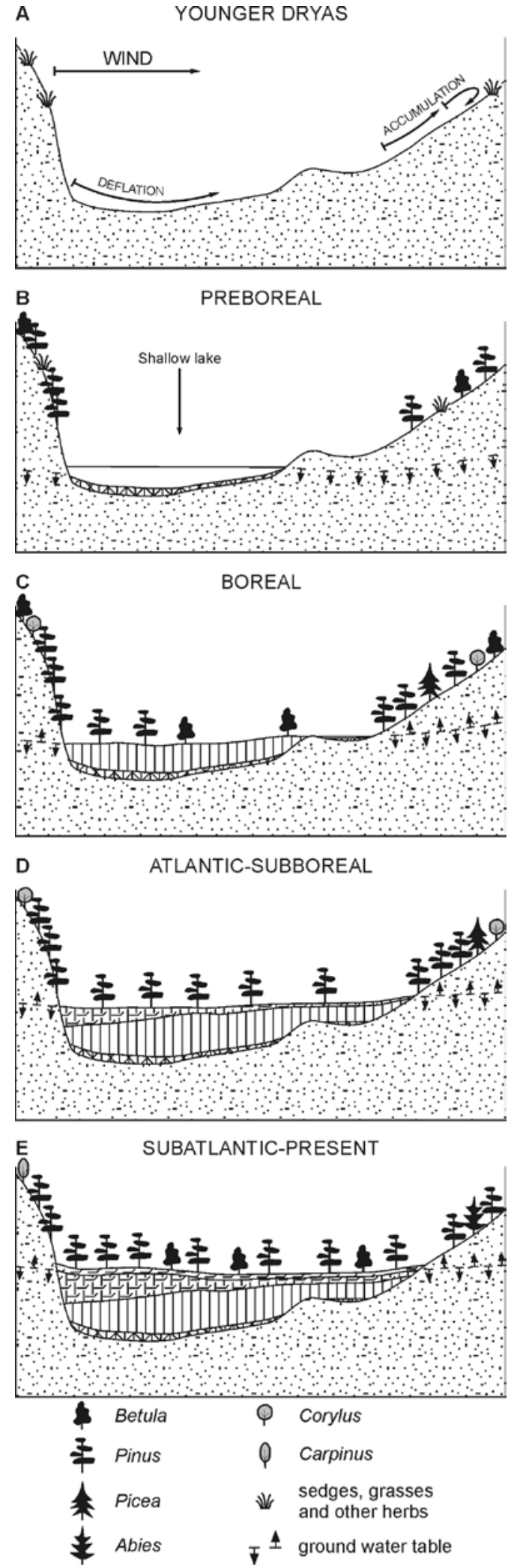

Fig. 5. Stages in evolution of the Poręby Wojsławskie (PW) ecosystem: $A$ - creation of the mid-dunes depression, $B$ - paralimnic phase with shallow lake, C-D - paludic phases with ground-water supply mainly, E-paludic phase with precipitation supply mainly. Symbols as in Fig. 2. 
cant lowering of water table, dated according to Kalis et al. (2003), to the Late Boreal period (9250-9340 cal BP).

Atlantic period. This period was characterized by a significant increase in the content of thermophilous trees in the regional vegetation surrounding the mire (Tilia, Fraxinus, Quercus, Ulmus, Acer), which is consistent with general pattern of vegetation composition in the Atlantic (Latałowa, 2003; Tobolski, 2004). Substantial fluctuations of water level in the area were observed, with a generally high water table. This was evidenced by, among others, the changes in the organic matter content. In more humid periods, the lake had relatively high variability of water level, which was indicated by the inserts of gyttja in the peat layers, as well as the presence of Sparganium and Phragmites in the pollen spectrum. During the entire Atlantic period, the pollen record contained traces of human activity. They were shown in the increase of the Pteridium aquilinum spores and in the presence of charcoal (effect of intentional fires). Nalepka et al. (2005), based on the high-resolution record from Stanisławice in the western part of the Sandomierz Basin, related the settlement phases with the carved ribbon ceramic culture dated in this area for $5300 \mathrm{cal} \mathrm{BC}$.

The Atlantic/Subboreal transition, documented by elm decline, the radiocarbon date, and low contents of organic matter, is related not only to climate-induced changes but to anthropogenic activity as well. Human impact was registered also in the Stanisławice profile (Nalepka et al., 2005) and the Jarosław-Kruchel one (Kołaczek, 2011) but the nature of vegetation changes and the anthropogenic activity in their formation are still the matter of debate (Mamakowa, 1962; Latałowa, 2003; Nalepka et al., 2005). Kołaczek (2007) considered an increase in charcoal content and Pteridium aquilinum spore values as traces of human activity of the Neolithic and early Bronze cultures which were archeologically documented in this region.

Subboreal period. In the second part of this period, in the western part of the mire, an expansion of reedswamp plants cover was observed, which could have pointed to a relative rise of water level. Initial swamping and the development of mire with sedge peat accumulation occurred in the eastern part of the depression as indicated by radiocarbon dating. Clearly registered in the pollen spectra was a phase of anthropogenic activity, documented by a decrease in the content of trees (Carpinus, Fagus, Ulmus, Fraxinus) and Corylus pollen and by the presence of pollen of plants - indicators of pasture activity (Behre, 1981; Makohonienko, 2004): Plantago lanceolata, Rumex acetosella, Chenopodiaceae, Urtica, increased content of Calluna vulgaris. Evidence for the cultivation of Triticum t. also begins at this time (sample $95 \mathrm{~cm}$ ). These changes could have been connected with the activity of the Lusatian Culture. Traces of this settlement were registered in Kopki (Bałaga and Taras, 2001), Grodzisko Nowe (Kołaczek, 2010) and JarosławKruchel (Kołaczek, 2011).
Subatlantic period. This period was characterized by a significant humidification of climate with a constant ombrotrophic character of inflow. Initially, water level on the mire was somewhat higher (the maximum content of Sphagnum spores with the minimum content of reedswamp plant pollen), with a tendency for its decrease in the younger phases of the Subantlantic period (increase in the content of Phragmites). Encroachment of Fagus and Abies into forest habitats, typical of this period (Tobolski 2004), is often related to increased humidity of air and soil (Huntley et al., 1989; Tinner and Lotter, 2006). Substantial influence on the mire transformation in the youngest phases of the Subatlantic was that of human activity. It was registered in the lithological record (decomposition of the Sphagnum peat), palynological data (presence of classic indicators of human activity sensu Behre, 1981). Due to the strong decomposition of the uppermost section of the Sphagnum peat, it was impossible to reconstruct in details the younger phases of the environmental changes in the investigated mire based on pollen spectra.

\section{CONCLUSIONS}

The collected documentation material, which included good correlations between all proxies and radiocarbon dating, allowed to draw local (related to the reconstruction of the evolutionary phases of the ecosystem), as well as regional conclusions (related to the Late Glacial/Holocene transition and in the Holocene changes in climate and hydrology).

1) The beginning of the biogenic sedimentation in the bottom of the deflation depression (in the paralimnic environment) is unequivocally determined by the change in climate (increase in air wetness and temperature) and hydrologic conditions related to the degradation of permafrost in the ground.

2) A gradual warming of climate in the Preboreal period favoured the change in the biogenic character of the deposition environment from paralimnic to paludic. Initially, the mire was supplied only with groundwater, but starting from the Late Preboreal period, increasingly significant was the precipitation water supply. The record of the fluctuations in the groundwater level, caused by the changes in supply character, is the high lithofacial variability of biogenic sediments (inserts of gyttja in sedge peat followed by an increasing content of Sphagnum peat) as well as the changes in the content of specific taxons from the Limnophyta and Telmatophyta groups, which were characteristic of various phases of the site's development.

3) From the Atlantic period, a slow but progressive influence of human activity on the environmental changes in the area around the mire can be documented by an increase of the values of the anthropopressure pollen indexes. 
4) Important influence of anthropopressure on the transformation of the mire was observed from the youngest phases of the Subboreal period.

\section{REFERENCES}

Bałaga K, 2004. Changes of vegetation in Lake Perespilno environs (Lublin Polesie) in the Late Glacial and Holocene. Acta Palaeobotanica 44(2): 147-166.

Bałaga K, 2007a. Changes the natural environment recorded in the sediments of the Kraśne Lake-mire complex (Lublin Polesie, E Poland). Geochronometria 29: 1-21, DOI 10.2478/v10003-007-0032$\mathrm{z}$.

Bałaga K, 2007b. Transformation of lake ekosystem into peat bog and vegetation history based on Durne Bagno mire (Lublin Polesie, E Poland). Geochronometria 29: 23-43, DOI 10.2478/v10003-0070033-y.

Bałaga K and Taras H, 2001. Development of vegetation and settlement near Kopki in the Sandomierz Basin during the last 4000 years. Acta Palaeobotanica 41: 69-81.

Bednarek R, Dziadowie H, Pokojska U and Prusinkiewicz Z, 2004. Badania ekologiczno-gleboznawcze (Ecological-soil investigations). Wydawnictwo Naukowe PWN. Warszawa. 344pp (in Polish).

Behre KE, 1981. The interpretation of anthropogenic indicators in pollen diagrams. Pollen et spores 23: 225-245.

Berglund BE and Ralska-Jasiewiczowa M, 1986. Pollen analysis and pollen diagrams. In: Berglund $\mathrm{BE}$ and Ralska-Jasiewiczowa M, eds., Handbook of Holocene Palaeoecology and Palaeohydrology. J. Wiley \& Sons Ltd., Chichester-Toronto: 455-484.

Bronk Ramsey C, 2009. Bayesian analysis of radiocarbon dates. Radiocarbon 51(1): 337-360.

Chambers FM and Charman DJ, 2004. Holocene Environmental change: contributions from the peatland archive. The Holocene 14(1): 1-6, DOI 10.1191/0959683604hl684ed.

Digerfeldt G, 1988. Reconstruction and regional correlation of Holocene lake-level fluctuations in Lake Bysjön, South Sweden. Boreas 17(2): 165-182, DOI 10.1111/j.1502-3885.1988.tb00544.x.

Dobrowolski R, Bałaga K, Bogucki A, Federowicz S, Melke J, Pazdur A and Zubovič S, 2001. Chronostratigraphy of the Okunin and Czerepach lake-mire geosystems (Volhynia Polesiye, NW Ukraine) during the late glacial and holocene. Geochronometria 20: $107-115$.

Dobrowolski R, Ziółek M, Bałaga K, Melke J and Bogucki A, 2010. Radiocarbon age and geochemistry of the infillings of small closed depressions from Western Polesie (Poland SE, Ukraine NW). Geochronometria 36: 39-46, DOI 10.2478/v10003-010-0010-8.

Domińczak P and Okupny D, 2010. Przestrzenne zróżnicowanie wybranych właściwości fizykochemicznych osadów biogenicznych torfowiska Kopanicha koło Skierniewic (Spatial variability of selected physicochemical properties of biogenic sediments in the Kopanicha peatland near Skierniewice). Prace Geograficz$n e$, z. 123. Instytut Geografii i Gospodarki Przestrzennej UJ. Kraków: 99-110 (in Polish).

Erdtman G, 1969. Handbook of palynology. Munsgaard, Copenhagen.

Faegri K and Iversen J, 1989. Textbook of Pollen Analysis. IV edition, Faegri K., Kkaland P.E. and Krzywinski K.J. Willey and Sons, Chichester.

FAO-ISRIC-ISSS, 1998. World Reference Base for Soil Resources (WRB). Report 84. FAO, Rome: $91 \mathrm{pp}$.

Huntley H, Bartlein PJ and Prentice IC, 1989. Climatic control on the distribution and abundance of beech (Fagus L.) in Europe and North America. Journal of Biogeography 16(6): 551-560.

Issmer K, 2009. Badania multiproxy - nowe trendy w badaniach paleoklimatycznych holocenu (Muliproxy researches as new trends in palaeoclimatic research of the Holocene methodology background). Geneza, litologia i stratygrafia utworów czwartorzędowych. Tom V. Seria Geograficzna nr 88: 109-125.
Janczyk-Kopikowa Z, 1987. Uwagi na temat palinostratygrafii czwartorzędu (Remarks on palynostratigraphy of the Quaternary). Kwartalnik Geologiczny 31(1): 155-162 (in Polish).

Kalis, AJ, Merkt J and Wunderlich J, 2003. Environmental changes during the Holocene climatic optimum in central Europe - human impact and natural causes. Quaternary Science Reviews 22(1): $33-$ 79, DOI 10.1016/S0277-3791(02)00181-6.

Kołaczek P, 2007. Late Glacial and Holocene vegetation changes in the western part of Rzeszów foothills (Sandomierz basin) based on the pollen diagram from Krasne near Rzeszów. Acta Palaeobotanica 47: 455-467.

Kołaczek P, 2010. The development of Late Glacial and Holocene vegetation and human impact near Grodzisko Nowe in the Lower San Valley (Sandomierz Basin, Poland SE). Acta Palaeobotanica 50: 101-117.

Kołaczek P, 2011. 12 Millennia of Climatic and Human Induced Vegetation Changes in the Lower San Valley Near Jarosław (SE Poland) in the Light of Pollen Analysis. Studia Quaternaria 28: 2539.

Kondracki J, 2009. Geografia regionalna Polski (Polish regional geography). Wydawnictwo Naukowe PWN. Warszawa: 441pp (in Polish).

Lamentowicz M, Gałka M, Pawlyta J, Lamentowicz Ł, Goslar T, and Miotek-Szpiganowicz G, 2011. Climat change and human impact in the Southern Baltic during the last millennium reconstructed from an ombrotrophic bog archive. Studia Quaternaria 28: 3-16.

Latałowa M, 2003. Holocen (The Holocene). In: S. Dybova-Jachowicz S and Sadowska A, eds., Palinologia. Kraków: 273-307 (in Polish).

Latałowa M, 2004. Late Glacial. In: Ralska-Jasiewiczowa M., Latałowa M., Wasylikowa K., Tobolski K., Madeyska E., Wright H.E. Jr, Turner C. (eds), Late Glacial and Holocene history of vegetation in Poland based on isopollen maps. W. Szafer Institute of Botany, Polish Academy of Sciences, Kraków: 385-391.

Macaire JJ, Bernard J, Di-Giovanni Ch, Hinschberger F, LimondinLozouet $\mathrm{N}$ and Visset L, 2006. Quantification and regulation of organic and mineral sedimentation in a late-Holocene floodplain as a result of climatic and human impacts (Taligny marsh, Parisian Basin, France). The Holocene 16(5): 647-660, DOI 10.1191/0959683606hl961rp.

Makohonienko M, 2004. Late Holocene period with increasing human impact. In: Ralska-Jasiewiczowa M., Latałowa M., Wasylikowa K., Tobolski K., Madeyska E., Wright H.E. Jr, Turner C. (eds), Late Glacial and Holocene history of vegetation in Poland based on isopollen maps. W. Szafer Institute of Botany, Polish Academy of Sciences, Kraków: 411-415.

Mamakowa K, 1962. Roślinność Kotliny Sandomierskiej w późnym glacjale i holocenie (The vegetation of the Basin of Sandomierz in the Late Glacial and Holocene). Acta Palaeobotanica 3: 1-57 (in Polish).

Mangerud J, Andersen ST, Berglund BE and Donner JJ, 1974. Quaternary stratigraphy of Norden, a proposal for terminology and classification. Boreas 3(3): 109-128, DOI 10.1111/j.15023885.1974.tb00669.x.

Mirek Z, Piękoś-Mirkowa H, Zając A and Zając M, 2002. Krytyczna lista roślin naczyniowych Polski (Flowering Plants and Pteridophytes of Poland. A checklist). Polish Academy of Sciences, W. Szafer Institute of Botany, Kraków.

Nalepka D, Nowak M and Zając M, 2005. Osadnictwo prehistoryczne i wczesnohistoryczne w zachodniej części Kotliny Sandomierskiej: konfrontacja danych archeologicznych i palinologicznych (stan badań do roku 2005) (Prehistoric and early historic settlement in the western part of Sandomierz Basin: comparison of archaeological and palynological data (state of research for 2005). In: Kuraś M, eds., Archeologia Kotliny Sandomierskiej. Rocznik Muzeum Regionalnego w Stalowej Woli, nr 4: 97-133 (in Polish).

Nalepka D and Walanus A, 2003. Data processing in pollen analysis. Acta Palaeobotanica 43: 125-134.

Nowaczyk B, 1986. Wiek wydm, ich cechy granulometryczne i strukturalne a schemat cyrkulacji atmosferycznej w Polsce w późnym vistulianie i holocenie (The age of Dunek, their textural 
and structural properties against atmospheric circulation pattern of Poland during the Late Vistulian and Holocene). UAM. Poznań: 245pp (in Polish).

Ostrowska A, Gawliński S and Szczubiałka Z, 1991. Metody analizy $i$ oceny właściwości gleb i roślin (Analyses and evaluation methods of soils and plants). Instytut Ochrony Środowiska. Warszawa: 334pp (in Polish).

Ralska-Jasiewiczowa M, 2004. Early Holocene. In: RalskaJasiewiczowa M., Latałowa M., Wasylikowa K., Tobolski K., Madeyska E., Wright H.E. Jr, Turner C. (eds), Late Glacial and Holocene history of vegetation in Poland based on isopollen maps. W. Szafer Institute of Botany, Polish Academy of Sciences, Kraków: 393-397.

Ralska-Jasiewiczowa M and Starkel L, 1988. Record of the hydrological changes during the Holocene in the lake, mire and fluvial deposits of Poland. Folia Quaternaria 57: 91-127.

Roos-Barraclough F, van der Knaap WO, van Leeuwen JFN and Shotyk W, 2004. A Late-glacial and Holocene record of climatic change from a Swiss peat humification profile. The Holocene 14(1): 7-19, DOI 10.1191/0959683604hl685rp.

Tinner W and Lotter AF, 2006. Holocene expansion of Fagus sylvatica and Abies alba in Central Europe: where are we after eight decades of debate? Quaternary Science Reviews 25(5-6): 526-549, DOI 10.1016/j.quascirev.2005.03.017.

Tobolski K, 2000. Przewodnik do oznaczania torfów $i$ osadów jeziornych (Handbook to the determination of peat and lake depos its). Warszawa, PWN, Vademecum Geobotanicum: 508 pp (in Polish).

Tobolski K, 2004. Middle Holocene. In: Ralska-Jasiewiczowa M., Latałowa M., Wasylikowa K., Tobolski K., Madeyska E., Wright H.E. Jr, Turner C. (eds), Late Glacial and Holocene history of vegetation in Poland based on isopollen maps. W. Szafer Institute of Botany, Polish Academy of Sciences, Kraków: 399-403.

Troels-Smith T, 1955. Karakteriserung af lose jordarter (Characterization of unconsolidated sediments). Danmarks Geologiske Undersøgelse, 4 (3/10): 1-73 (in Danish).

West RG, 1970. Pollen zones in the Pleistocene of Great Britain and their correlations. New Phytologist 69(4): 1179-1183, DOI 10.1111/j.1469-8137.1970.tb02498.x.

Willis KJ, Sümegi P, Braun M and Tóth A, 1995. The late Quaternary Environmental history of Bátorliget, NE Hangary. Palaeogeography, Palaeoclimatology, Palaeoecology 118(1-2): 25-47, DOI 10.1016/0031-0182(95)00004-6.

Wojtanowicz J, 1971. Typy genetyczne wydm Niziny Sandomierskiej (Genetic types of dunes of the Sandomierz Basin). Annales UMCS, S. B, Vol. 24(1), 1969: 1-45 (in Polish).

Zachowicz J, Ralska-Jasiewiczowa M, Miotk-Szpiganowicz G and Nalepka D, 2004. Ulmus L. - Elm. In: Ralska-Jasiewiczowa M., Latałowa M., Wasylikowa K., Tobolski K., Madeyska E., Wright H.E. Jr, Turner C. (eds), Late Glacial and Holocene history of vegetation in Poland based on isopollen maps. W. Szafer Institute of Botany, Polish Academy of Sciences, Kraków: 225-236. 